\title{
PENGARUH PENERAPAN METODE TERAPI KOMUNIKASI TOTAL TERHADAP PASIEN AFASIA GLOBAL PASCA STROKE
}

\author{
Hendra Djuhendi ${ }^{*}$,Popon \\ Prodi Diploma Tiga Terapi Wicara Politeknik Al Islam Bandung \\ Email: hendradjuhendi07@gmail.com
}

\begin{abstract}
ABSTRAK
Individu penderita afasia mengalami gangguan berbicara, mendengarkan dan menulis walaupun tidak mempengaruhi kecerdasan akibat kerusakan otak yang mengandung Bahasa biasanya pada sisi kiri hemisfer serebri otak kiri. Kasus afasia dapat ditangani dengan metode semantic divergen. Penelitian ini bertujuan untuk mengetahui penanganan pasien Afasia dewasa yang memiliki gangguan dalam penemuan kata, merangkai kalimat yang kadang mengekspresikannya tidak menggunakan susunan kalimat yang benar, dengan metode semantic divergen. Terdapat juga ada beberapa pasien mengalami gangguan dalam hubungan antara proses pikir dan bahasa; ketidakmampuan untuk mengalihkan pikiran ke dalam kalimat. Penelitian ini dilakukan pada pasien Afasia Global Pasca Stroke jenis kelamin perempuan usia 84 tahun Di Rumah Sakit Umum Daerah Cibabat Cimahi. Metode penelitian yang digunakan adalah eksperimen penelitian studi kasus yang bertujuan untuk mengetahui keadaan subjek sebelum dan sesudah intervensi atau terapi. Pengumpulan data dilakukan melalui tahap WOTS yaitu Wawancara dengan orang tua klien, Observasi secara langsung terhadap klien, melakukan Tes kepada klien, dan Studi dokumen rekam medis pasien. Hasil penelitian menunjukkan bahwa setelah dilakukan terapi sebanyak 20 kali pertemuan, kemampuan menunjuk tingkat kata benda pasien mengalami peningkatan di mana pada tes awal mendapat skor sebanyak 0 poin dan tes akhir mendapatkan skor sebanyak 8 poin dengan persentase keberhasilan $80 \%$ dari 10 poin maksimal yang diteskan. Berdasarkan hasil tersebut dapat disimpulkan bahwa penerapan metode komunikasi total pada pasien afasia global dikatakan berhasil.
\end{abstract}

Kata kunci: Afasia, gangguan bicara, metode semantic divergen.

\begin{abstract}
Individuals with aphasia experience speech, listening and writing disorders although they do not affect intelligence due to brain damage which contains language, usually on the left side of the left cerebral hemisphere. Aphasia cases can be handled by semantic divergent methods. This study aims to determine the treatment of adult aphasia patients who have impaired word discovery, compose sentences that sometimes express them not using the correct sentence structure, using the semantic divergent method. There were also some patients who experienced disturbances in the relationship between thought processes and language; the inability to turn thoughts into sentences. This study was conducted on a female patient with Global Aphasia


Post Stroke aged 84 years at the Cibabat Regional General Hospital, Cimahi. The research method used is experimental case study research which aims to determine the condition of the subject before and after intervention or therapy. Data collection was carried out through the WOTS stage, namely interviews with the client's parents, direct observation of clients, conducting tests on clients, and study of patient medical record documents. The results showed that after 20 sessions of therapy, the ability to designate the patient's noun level increased were the initial test scored 0 points and the final test scored 8 points with a s.

Key words: Afasia, speech disorder, divergen semantic method

\section{PENDAHULUAN}

Secara harfiah komunikasi mempunyai arti pemberitahuan, pembicaraan, percakapan, pertukaran pikiran atau hubungan. Selain itu juga ditemukan arti dari komunikasi, yaitu: Dipahami, Hubungan atau saling berhubungan, Saling pengertian, dan Pesan. Setiap hari manusia selalu berbicara, maksudnya berkomunikasi, atau membicarakan tentang komunikasi. Kata komunikasi mempunyai konsep yang serba makna yaitu sebagai proses sosial, sebagai peristiwa, sebagai ilmu, dan sebagai kiat atau keterampilan (Lestari \& Maliki, 2006).

Stroke adalah gangguan pembuluh darah otak (GDPO)/ Cerebro Vascular Disease (CVD)/Cerebro Vascular Accident (CVA) merupakan suatu kondisi kehilangan fungsi otak secara mendadak yang diakibatkan oleh gangguan suplai darah ke bagian otak (Brunner \& Suddarth, 2000 dalam Tammase, 2013).

Stroke dapat menyebabkan penderita mengalami afasia. Menurut Dharmaperwira-Prins (2002), Afasia merupakan gangguan bahasa perolehan yang disebabkan oleh cedera otak dan ditandai oleh gangguan pemahaman serta gangguan pengutaraan bahasa, lisan maupun tertulis. Penderita afasia dapat mendengar orang lain berbicara, tetapi ia mengalami kesulitan untuk memahami mereka. Ia dapat melihat dengan baik huruf buku atau surat kabar, tetapi tidak mengerti apa yang tertera disitu. Afasia bisa sedemikian parah hingga pasien hampir tidak dapat mengatakan atau memahami sesuatu pun.

Berdasarkan ilmu terapi wicara dijelaskan banyak metode terapi yang digunakan untuk meningkatkan kemampuan bahasa pada kasus afasia. Salah satu metode yang dipilih oleh peneliti yaitu metode terapi "Komunikasi Total" yang mana terapi yang bertujuan untuk meningkatkan kemampuan menunjuk tingkat kata benda dengan kategori pakaian dan peralatan makan. Oleh karena itu, dengan metode tersebut dapat meningkatkan kemampuan pemahaman bahasanya, maka penderita akan diberi latihan.

Peneliti memiliki tugas untuk memandu setiap latihan yang diberikan kepada pasien atau penderita, dengan langkah-langkah yang di mulai dengan suruhan/perintah yang mudah difahami dan kemudian meningkat pada yang lebih sulit. Misalnya: "tunjukkan gelas", kemudian "tunjukkan gelas yang ada disamping televisi".

Tujuan penelitian ini yang hendak di capai adalah mendeskripsikan Pengaruh penerapan Komunikasi Total Untuk Meningkatkan Kemampuan Menunjuk Pada Tingkat Kata Benda Pada Pasien Afasia 
Global Pasca Stroke Jenis kelamin Perempuan Usia 84 tahun di Rumah Sakit Umum Daerah Cibabat Cimahi".

\section{METODOLOGI PENELITIAN}

Jenis penelitian yang dilakukan pada adalah studi kasus. yaitu pendekatan kualitatif yang mempelajari fenomena khusus yang terjadi saat ini dalam suatu sistem yang terbatasi oleh waktu dan tempat, meski batas-batas antara fenomena dan sistem tersebut tidak sepenuhnya jelas (Creswell, 2013).

Fenomena yang menjadi kasus dalam penulisan ini adalah untuk meningkatkan kemampuan menunjuk tingkat kata benda.

Tabel 1. Pre Test dan Post Test

Pre Test Perlakuan Post tes

\begin{tabular}{lll}
\hline $\mathbf{T}_{\mathbf{0}}$ & $\mathrm{X}$ & $\mathrm{T}_{1}$ \\
\hline
\end{tabular}

Berdasarkan langkah-langkah diatas dan dengan rumusan jumlah peningkatan seperti dibawah ini:

$$
\mathrm{T}_{1}-\mathrm{T}_{0}=\text { Jumlah Peningkatan }
$$

Keterangan:

$\mathrm{T}_{0}:$ Sebelum dilakukan terapi

$\mathrm{X}$ : Perlakuan atau kegiatan terapi

$\mathrm{T}_{1}:$ Sesudah dilakukan terapi

\section{Desain Penelitian}

Beberapa tahapan dapat dilakukan peneliti untuk melakukan penelitian studi kasus, Yin (2009) menentukan kasus yang akan dipelajari dan berusaha untuk memberikan pemahaman mendalam dari kasus, mengidentifikasi kasus secara jelas, baik dari waktu kejadian maupun tempat kejadian, melakukan pengumpulan data dengan cara observasi, wawancara, dan penelusuran dokumen, melakukan analisis data, dan peneliti melaporkan dari kasus yang diteliti. Penelitian ini dilakukan di Rumah Sakit Umum Daerah Cibabat Cimahi dan di rumah pasien dan dilakukan selama 2 bulan terhitung sejak Januari 2019 hingga Maret 2019.

\section{Metode Komunikasi Sosial}

Metode Terapi komunikasi total adalah terapi yang dikembangkan di Negeri Belanda dimaksudkan bagi pasien-pasien dengan afasia berat dan lingkungannya. Pasien disodori segala macam cara komunikasi yang dapat ia pahami dan gunakan (dengan cara belajar). Cara-cara ini ialah; menunjuk, menyatakan besarnya sesuatu, memberi gerak-isyarat, menggambar, menulis dan mencari dalam kamus kantong, di samping menggunakan bahasa biasa. Kamus kantong berupa kumpulan kata-kata dan gambar-gambar yang disusun dalam sejumlah kategori, seperti makan, minum, angkutan. Lingkungan (partner, keluarga, tenaga perawatan) pun belajar menggunakan kamus kantong ini. 
Metode ini digunakan karena sesuai untuk penanganan pasien Afasia dewasa yang mana ada beberapa pasien memiliki gangguan dalam penemuan kata, merangkai kalimat yang kadang mengekspresikannya tidak menggunakan susunan kalimat yang benar, beberapa Pasien dapat mengulang satu kata atau kalimat pendek, tetapi pada kalimat yang lebih panjang timbul perseverasi, kadang juga ada beberapa pasien mengalami gangguan dalam hubungan antara proses pikir dan bahasa; ketidakmampuan untuk mengalihkan pikiran ke dalam kalimat.

Dalam penanganan afasia dapat digunakan tugas bahasa konvergen kepada pasien yaitu dengan memberikan suatu stimulus yang memungkinkan hanya satu jawaban, seperti menyebutkan nama suatu gambar. Misalkan Terapis meberikan suatu gambar kartu fonem kategori tertentu diharapkan pasien dapat mengingat apa yang menjadi kesulitannya.

\section{HASIL DAN PEMBAHASAN}

\section{Afasia}

Menurut Peraturan Menteri Kesehatan Tahun 2014, Afasia adalah gangguan bahasa perolehan yang disebabkan oleh cedera otak dan ditandai oleh gangguan pemahaman serta gangguan pengutaraan bahasa. Afasia dewasa adalah gangguan bahasa perolehan yang disebabkan oleh cedera otak dan ditandai oleh gangguan pemahaman serta gangguan pengutaraan bahasa (PMK no. 81 tahun 2014).

Afasia global ialah bentuk afasia yang paling berat. Keadaan ini ditandai oleh tidak adanya lagi bahasa spontan atau berkurang sekali dan menjadi beberapa patah kata yang diucapkan secara stereotip (itu-itu saja, berulang), misalnya: "iiya, iiya, iiya", atau: "baaah, baaaah, baaaah", atau: "amaaang, amaaaaang, amaaaang". Komprehensi menghilang atau sangat terbatas, misalnya hanya mengenal namanya saja atau satu atau dua patah kata. Repetisi (mengulangi) juga sama berat gangguannya seperti bicara spontan. Membaca dan menulis juga terganggu berat (Lumbantobing, 2013:170).

Menurut Purwani (2017), Stroke disebabkan oleh:

1. Faktor yang tidak dapat dikendalikan

Faktor yang tidak dapat dikendalikan ini merupakan faktor risiko alami yang dimiliki oleh setiap orang, contohnya usia, jenis kelamin, riwayat keluarga, dan suku/ras.

2. Faktor yang dapat dikendalikan

Faktor-faktor ini meliputi gaya hidup tidak sehat yang tentunya dapat dikurangi atau malah dihilangkan sama sekali. Gaya hidup merupakan perilaku sehari-hari seseorang yang lamakelamaan menjadi kebiasaan. Beberapa hal yang berhubungan dengan gaya hidup yang dapat memicu terjadinya stroke adalah penyakit hipertensi, dislipidemia, diabetes melitus, kegemukan, kelainan jantung, kebiasaan merokok, diet, mengkonsumsi alkohol, dan aktivitas fisik yang minim.

Penyebab-penyebab Afasia menurut Dharmaperwira-Prins (2002), diantara lain: (1) Gangguan Peredaran Darah Otak (GDPO), (2) Trombosis, (3) Emboli, (4) Perdarahan Otak, (5) Tumor Otak, (6) Trauma

Menurut Lumbantobing (2013:171), Afasia global disebabkan oleh lesi luas yang merusak sebagian besar atau semua daerah bahasa. Penyebab lesi yang paling sering ialah oklusi arteri karotis interna atau arteri serebri media ada pangkalnya. Kemungkinan pulih ialah buruk. Afasia global hampir selalu disertai hemiparese atau hemiplegia yang menyebabkan invaliditas kronis yang parah. 
Tabel 2. Klasifikasi Afasia

\begin{tabular}{llll}
\hline Jenis afasia & $\begin{array}{c}\text { Kelancaran } \\
\text { perkataan }\end{array}$ & pemahaman & Meniru \\
\hline Afasisa global & Tidak lancar & - & - \\
\hline Afasia broca & Tidak lancar & + & - \\
\hline $\begin{array}{c}\text { Afasia transkortikal } \\
\text { motoris }\end{array}$ & Tidak lancar & + & + \\
\hline $\begin{array}{l}\text { Afasia transkortikal } \\
\text { campuran }\end{array}$ & Tidak lancar & - & + \\
\hline Afasia wernicke & Lancar & - & - \\
\hline $\begin{array}{l}\text { Afasia transkortikal } \\
\text { sensoris }\end{array}$ & Lancar & - & + \\
\hline Afasia konduksi & Lancar & + & - \\
\hline Afasia anomis & Lancar & + & + \\
\hline
\end{tabular}

Sumber: Goodglass dan Kaplan, 1973

Menurut Dharmaperwira-Prins (2002), karakteristik afasia global yaitu, (1) bicara spontan sangat tidak lancar, (2) memiliki beberapa kata atau ucapan stereotip, (3) pemahaman auditif sangat terganggu, (3) menunjuk biasanya juga tidak bisa lagi sehingga memeriksa pemahaman auditif menjadi sangat sukar, (4) terkadang nampak dari reaksi nonverbal bahwa pasien lebih banyak mengerti daripada yang muncul dari hasil pemeriksaan, (5) meniru ucapan, membaca dan dengan bersuara dan menulis sesuatu sama sekali tidak mungkin dilakukan, (6) hemiplegia kanan, (7) hemianopsia

\section{Dampak Gangguan Afasia Global Paska Stroke Pada Klien}

Gangguan berbahasa afasia Global Pasca Stroke, Afasia global merupakan afasia paling berat dan biasanya terjadi ketika seseorang baru saja mengalami stroke. Afasia global biasanya disebabkan oleh kerusakan yang luas pada otak. Penderita afasia global akan kesulitan bahkan tidak mampu membaca, menulis, serta memahami perkataan orang lain, merupakan jenis afasia yang paling parah. Seseorang dengan afasia global hanya mampu memproduksi beberapa kata yang dapat dimengerti dan tidak dapat atau hanya sedikit mengerti apabila diajak berbicara. Penderita afasia ini tidak mampu membaca maupun menulis

Prosedur Pengumpulan Data Data dikumpulkan dengan menggunakan prosedur sebagai berikut:

a. Wawancara Interview atau wawancara yang akan sudah dilakukan dalam penelitian ini adalah bebas terpimpin, yaitu peneliti mengajukan pertanyaan kepada informan berdasarkan pedoman interview yang telah disiapkan secara lengkap dan cermat, dengan suasana tidak formal. Tujuan dari wawancara ini adalah menemukan aspek-aspek gangguan berbahasa.

b. Observasi Observasi merupakan tehnik pengumpulan data yang digunakan dalam penelitian kualitatif. Metode observasi nonpartisifan ini dimaksudkan untuk memperoleh data yang lebih rinci dan lengkap dengan menggunakan pengamatan secara seksama dengan cara melibatkan diri pada komunitas tanpa berpartsifasi dalam fokus penelitian yang sedang diteliti. Observasi diklasifikasikan menjadi tiga cara yaitu: (1) bertindak sebagai pertisipan dan nonpartisipan, (2) 
dilakukan secara terus terang dan (3) dilakukan dengan latar alami. Data yang diambil dengan Observasi adalah data yang dapat dilihat ketika peneliti melakukan penelitian.

c. Dokumentasi adalah data yang bersumber dari dokumen-dokumen sebagai laporan tertulis dari peristiwa-peristiwa yang isinya terdiri dari penjelasan-penjelasan dan pemikiran-pemikiran, peristiwa itu ditulis dengan kesadaran dan kesengajaan untuk menyiapkan atau meneruskan keterangan-keterangan pristiwa, dan bila perlu dilengkapi dengan lampiran foto-foto dokumentasi penelitian. Metode ini digunakan sebagai pelengkap dari metode yang telah disebutkan di atas. gedung, pamplet, lokasi ditengah kota atau di masyarakat tempat berdirinya gedung pasar yang berdiri dan lain sebagainya.

Tabel 3 Teknik, Instrumen Responden dan Indikator Penelitian

\begin{tabular}{|c|c|c|c|c|}
\hline No & $\begin{array}{c}\text { Teknik pengumpulan } \\
\text { data }\end{array}$ & Instrumen & Responden & Indikator \\
\hline 1. & $\begin{array}{l}\text { Inform Consent dan } \\
\text { wawancara }\end{array}$ & $\begin{array}{l}\text { Format } \\
\text { Informed } \\
\text { Consent dan } \\
\text { wawancara } \\
\text { (guide } \\
\text { interview) }\end{array}$ & $\begin{array}{l}\text { Keluarga } \\
\text { pasien }\end{array}$ & $\begin{array}{l}\text { Sebagai persetujuan } \\
\text { dilakukan pengambilan } \\
\text { data dan untuk } \\
\text { mendapatkan data } \\
\text { berupa; identitas, } \\
\text { keluhan yang terlihat } \\
\text { dan atau yang dirasakan, } \\
\text { faktor yang berkaitan } \\
\text { dengan penyebab yang } \\
\text { terdapat pada diri } \\
\text { pasien. }\end{array}$ \\
\hline 2. & Observasi & $\begin{array}{l}\text { Format } \\
\text { observasi }\end{array}$ & Pasien & $\begin{array}{l}\text { Untuk mendukung hasil } \\
\text { wawancara yang telah } \\
\text { dilakukan meliputi } \\
\text { kondisi fisik, } \\
\text { kemampuan motorik, } \\
\text { sensorik, bahasa, } \\
\text { wicara, suara, irama } \\
\text { kelancaran, menelan } \\
\text { serta kondisi yang } \\
\text { relevan lainnya. }\end{array}$ \\
\hline 3. & $\begin{array}{l}\text { Pemeriksaan Alat } \\
\text { Wicara }\end{array}$ & Format PAW & Pasien & $\begin{array}{l}\text { Untuk melihat keutuhan } \\
\text { dan kemampuan } \\
\text { struktur maupun fungsi } \\
\text { organ wicara berupa } \\
\text { bibir, gigi, lidah, langit- } \\
\text { langit keras, langit- } \\
\text { langit lunak, } \\
\text { palatopharinx, fauces, } \\
\text { nasal cavities, serta } \\
\text { pergerakan oral yang } \\
\text { disengaja. }\end{array}$ \\
\hline
\end{tabular}




\begin{tabular}{|c|c|c|c|c|}
\hline 4. & $\begin{array}{l}\text { Tedyva ( Tes Dysartria } \\
\text { dan Apraksia Verbal) }\end{array}$ & $\begin{array}{l}\text { Buku Tedyva } \\
\text { dan format tes } \\
\text { Tedyva }\end{array}$ & Pasien & $\begin{array}{l}\text { Dilakukan untuk } \\
\text { memperoleh data dari } \\
\text { pasien yang mungkin } \\
\text { mengalami disartria }\end{array}$ \\
\hline 5. & Token Test & $\begin{array}{l}\text { Format Token } \\
\text { Test }\end{array}$ & Pasien & $\begin{array}{l}\text { Untuk menentukan } \\
\text { adanya gangguan } \\
\text { reseptif. }\end{array}$ \\
\hline 6. & $\begin{array}{l}\text { TADIR (Tes Afasia } \\
\text { untuk Diagnosa, } \\
\text { Informasi dan } \\
\text { Rehabilitasi) }\end{array}$ & $\begin{array}{l}\text { Buku Tadir dan } \\
\text { format tes Tadir }\end{array}$ & Pasien & $\begin{array}{l}\text { untuk menentukan } \\
\text { diagnosa afasia/ bukan } \\
\text { afasia dan termasuk } \\
\text { sindroma afasia yang } \\
\text { mana serta menjadi titik } \\
\text { tolak ukur penanganan } \\
\text { terapi wicara. }\end{array}$ \\
\hline 7. & Tes Suara & $\begin{array}{l}\text { Format tes } \\
\text { Suara }\end{array}$ & Pasien & $\begin{array}{l}\text { Untuk mengetahui } \\
\text { apakah terjadi kelainan } \\
\text { pada nada, kenyaringan } \\
\text { dan kualitas suara } \\
\text { pasien saat ini. }\end{array}$ \\
\hline 8. & Tes Irama Kelancaran & $\begin{array}{l}\text { Format tes } \\
\text { irama } \\
\text { kelancaran }\end{array}$ & Pasien & $\begin{array}{l}\text { Untuk mengetahui } \\
\text { apakah terjadi kelainan } \\
\text { dalam berirama (berupa } \\
\text { perpanjangan, } \\
\text { pengulangan, } \\
\text { penghentian ataupun } \\
\text { penahanan) pada saat } \\
\text { bernyanyi, berbicara } \\
\text { ataupun berhitung. }\end{array}$ \\
\hline 9. & $\begin{array}{l}\text { Anamnesa Makan dan } \\
\text { Minum, Tes Menelan }\end{array}$ & $\begin{array}{l}\text { - Format } \\
\text { wawancara } \\
\text { makan dan } \\
\text { Minum, } \\
\text { - Format status } \\
\text { Fungsi } \\
\text { menelan } \\
\text { - Pemeriksaan } \\
\text { klinis disfagia }\end{array}$ & Pasien & $\begin{array}{l}\text { Untuk mengetahui } \\
\text { apakah ada kelainan } \\
\text { (gangguan menelan) } \\
\text { yang terjadi pada saat } \\
\text { pasien menelan cairan, } \\
\text { mengunyah dan } \\
\text { menelan makanan } \\
\text { melalui wawancara } \\
\text { kepada keluarga pasien. }\end{array}$ \\
\hline 10. & Studi Dokumen & - & $\begin{array}{l}\text { Hasil CT- } \\
\text { Scan }\end{array}$ & $\begin{array}{l}\text { Untuk bahan pelengkap } \\
\text { dan penguat data yang } \\
\text { didapatkan dari ahli lain }\end{array}$ \\
\hline 11. & Tes Awal dan Tes Akhir & $\begin{array}{l}\text { Format tes } \\
\text { awal dan tes } \\
\text { akhir }\end{array}$ & Pasien & $\begin{array}{l}\text { Untuk mengetahui } \\
\text { keberhasilan terapi yang } \\
\text { dicapai dengan } \\
\text { membandingkan kedua } \\
\text { hasil tes tersebut. }\end{array}$ \\
\hline 12. & Alat Penunjang Terapi & $\begin{array}{l}\text { - Tensimeter } \\
\text { - Stetoskop }\end{array}$ & Pasien & $\begin{array}{l}\text { Untuk mengukur } \\
\text { tekanan darah pasien }\end{array}$ \\
\hline
\end{tabular}




\section{- stopwatch \\ Untuk menghitung jeda \\ yang mungkin terjadi \\ saat pelaksanaan terapi}

Berdasarkan hasil wawancara dengan keluarga pasien, diperoleh keterangan bahwa pasien terkena stroke pada tahun 2017 di usia 84 tahun, karena pasien memiliki penyakit hipertensi. Berdasarkan hasil pemeriksaan dokter didapatkan bahwa tekanan darah pasien tinggi yaitu 210/91 $\mathrm{mmHg}$.

Menurut Mursyid Bustami (2011) Hipertensi merupakan faktor risiko independen terhadap serangan stroke. Penderita hipertensi seharusnya memeriksa tekanan darahnya secara teratur. Tekanan darah diusahakan mencapai target dibawah 140/85 mmHg. Pada penderita prehipertensi (120-139/80-90 $\mathrm{mmHg}$ ) dengan penyakit ikutan yang lain seperti penyakit jantung kongestif, infark miokard, diabetes atau gagal ginjal kronis perlu diberikan antihipertensi segera.

Kemudian keluarga pasien mengeluh bahwa ketika sebelum terjadi nya stroke pasien mengalami jatuh. Lalu pasien dibawa ke RSUD Cibabat Cimahi dan di rawat selama 4 hari dikarenakan pegawai rumah sakit cuti lebaran, dan pasien disarankan oleh dokter untuk dirawat dirumah selama beberapa minggu, tetapi tetap masih harus kontrol kerumah sakit dua minggu sekali. Setelah pasien rutin kontrol, dokter menyarankan pasien untuk terapi dengan terapi wicara, fisioterapi dan okupasi terapi dikarenakan pasien mengalami kesulitan bicara yang disebabkan adanya gangguan bahasa dan motorik kasar maupun motorik halus nya.

Berdasarkan hasil CT-Scan diperoleh hasil bahwa pasien menderita Afasia yang di sebabkan dari stroke.

Menurut Subyantoro (2013), gangguan berbahasa atau afasia berasal dari gejala sisa stroke.

Berdasarkan hasil tes TADIR, pasien tidak mampu bicara spontan dengan lancar, menyebut, menamai pada tingkat kata maupun kalimat, berceritera, membaca bersuara pada tingkat kata maupun kalimat, meniru ucapan pada tingkat kata maupun kalimat, pemahaman bahasa lisan dan tertulis pada tingkat kata maupun kalimat nya terganggu, dan menulis pada tingkat kata maupun kalimat nya juga terganggu.

Karakteristik afasia global yaitu bicara spontan sangat tidak lancar, meniru ucapan, membaca dan dengan bersuara dan menulis sesuatu sama sekali tidak mungkin dilakukan (Prins, 2002).

Berdasarkan tes dominan/lateralisasi diketahui bahwa klien dominan menggunakan tangan kirinya dikarenakan pasien mengalami hemiplegia kanan.

Gangguan menelan adalah kesulitan memindahkan cairan dan atau Menurut Dharmaperwira-Prins (2002), Karakteristik afasia global yaitu adanya hemiplegia kanan.

Berdasarkan observasi didapatkan data bahwa keluarga pasien sangat mendukung untuk kesembuhan pasien, dan pasien juga rutin untuk terapi di rumah sakit maupun di rumahnya. 
Salah satu dukungan keluarga yang dapat diberikan yakni dengan melalui perhatian secara emosi, diekspresikan melalui kasih sayang dan motivasi anggota keluarga yang sakit agar terus berusaha mencapai kesembuhan (Friedman, M, 2010).

Pada saat menelan makanan atau minuman pasien tidak mengalami tersedak dan bahkan makanan dan minuman tersebut keluar melalui hidung.

Menurut Peraturan Menteri Kesehatan no 81 tahun 2014 bolus dari rongga mulut bagian depan ke belakang menuju faring, esofagus, daerah dada dan ke dalam perut yang dapat disebabkan oleh patologik, neurologik dan psikologik.

Mengenai sindroma yang berhubungan dengan wicara. Berdasarkan hasil Pemeriksaan Alat Wicara (PAW) didapat hasil bahwa organ artikulasi pasien tidak terdapat gangguan yang dapat mempengaruhi pada bicara pasien. Hanya saja pasien mengalami gangguan pemahaman bahasanya sehingga mempersulit pasien untuk dapat berkomunikasi dengan orang lain yang ada di sekitarnya.

Gangguan pergerakan organ bicara ini akan mempengaruhi kemampuan pernapasan, fonasi, dan terutama kemampuan artikulasi dan resonansi (Setyono, 2000). Menurut lumbantobing (2013), ketidakmampuan melakukan gerakan terampil dari otot wajah dan otot berbicara sedangkan komprehensi, tenaga otot, dan kordinasi otot normal.

Mengenai sindroma yang berhubungan dengan irama kelancaran. Berdasarkan hasil TEDYVA dalam item tes bicara spontan terdapat bahwa pasien mengalami ketidak lancaran pada saat pasien bicara spontannya. Dan dalam item tes membaca bersuara tidak terdapat perpanjangan, tidak terdapat penghentian dan tidak terdapat penahanan, namun terdapat pengulangan pada saat pasien bicara atau stereotip.

Karakteristik pasien afasia global, bicara spontan sangat tidak lancar, bicara spontan sangat tidak lancar, memiliki beberapa kata atau ucapan stereotip (Dharmaperwira-Prins, 2002).

Mengenai sindroma yang berhubungan dengan suara. Berdasarkan hasil observasi yang telah dilakukan penulis, diketahui bahwa suara pasien terdengar lemah.

Menurut Sardjono (2014), Suara yang normal harus mempunyai 3 sifat penting diantaranya yaitu pitch, quality, dan loudness semuanya dapat membuat suara itu terang, wajar dan enak didengar oleh manusia. Apabila tidak memenuhi syarat dari ketiga sifat tersebut maka yang bersangkutan mengalami kelainan suara (voice disorder).

Mengenai sindroma yang berhubungan dengan bahasa. Berdasarkan hasil Token Test, diketahui bahwa pasien terdapat gangguan pemahaman bahasanya atau afasia. Berdasarkan hasil test TADIR, diketahui bahwa pasien terdapat afasia dengan sindroma afasia global. Sebagaimana dijelaskan dalam buku TADIR, diagnosis sindroma afasia dilakukan dengan skor-skor subtes-subtes sebagai berikut: dan dapat dilihat dari penilaian test TADIR sebagai berikut:

1. Skor kelancaran : lancar/tidak lancar

2. Skor Norma : :PEMAHAMAN BAHASA LISAN'tingkat kata + tingkat kalimat

3. Skor Norma : 'BICARA-meniru ucapan 


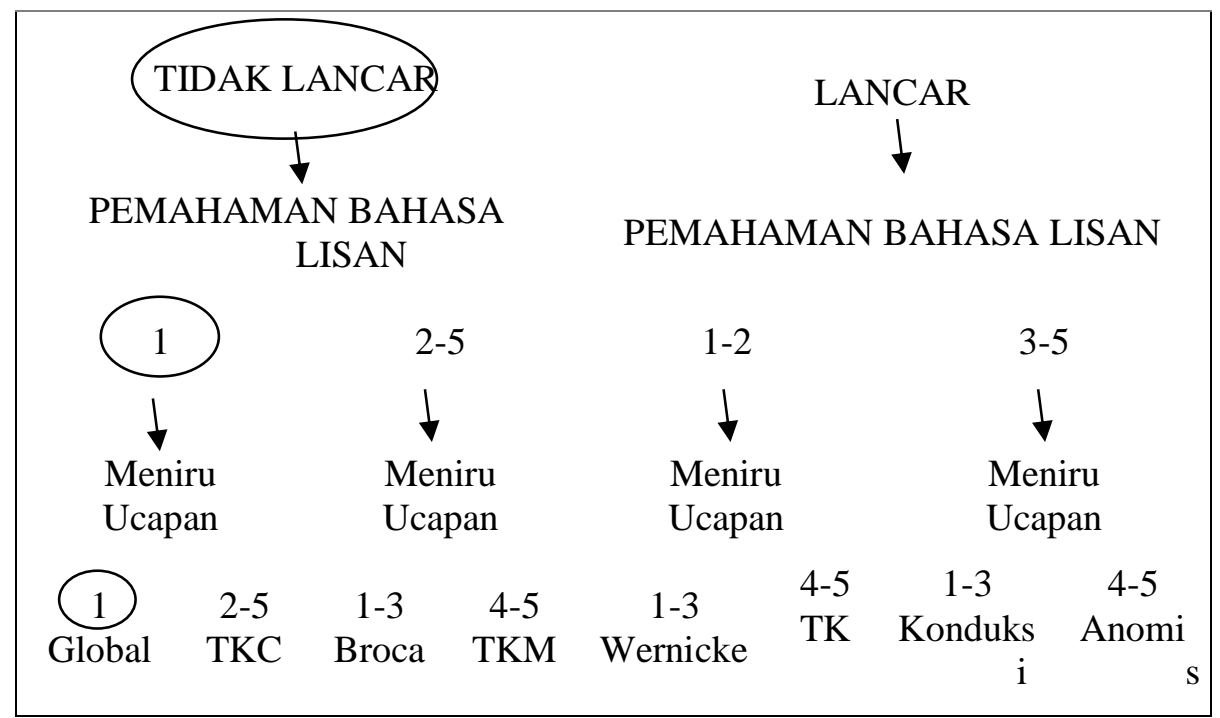

Gambar 1. Diagnosis Sindrom Afasia

\section{Hasil Pelaksanaan Terapi}

Metode yang digunakan adalah Metode Terapi komunikasi total, yaitu terapi yang dikembangkan di Negeri Belanda ini dimaksudkan bagi pasien-pasien dengan afasia berat dan lingkungannya. Pasien disodori segala macam cara komunikasi yang dapat ia pahami dan gunakan (dengan cara belajar). Cara-cara ini ialah; menunjuk, menyatakan besarnya sesuatu, memberi gerak-isyarat, menggambar, menulis dan mencari dalam kamus kantong, di samping menggunakan bahasa biasa. Kamus kantong berupa kumpulan kata-kata dan gambar-gambar yang disusun dalam sejumlah kategori, seperti makan, minum, angkutan. Lingkungan (partner, keluarga, tenaga perawatan) pun belajar menggunakan kamus kantong ini.

metode penanganan bagi pasien-pasien dengan gangguan sintaksis. Dengan penyajian suatu bagan kalimat (kunci-kunci visual), pengutaraan kalimat lengkap dipermudah. Jenis-jenis kata dalam hal ini dibedakan secara visual karena kata benda, kata kerja, kata sandang dan kata depan masing-masing mempunyai lambang tersendiri (secara berturut-turut: bujur sangkar, persegi empat panjang berbaring, persegi empat panjang berdiri, dan sebuah segi tiga). Banyak perhatian yang dicurahkan pada kata kerja karena hal ini sering membawa persoalan-persoalan khusus bagi pasien afasia

Yang mendjadi dasar pemiliran dari metode Intervensi semantik devergen adalah bahwa dalam kehidupan sehari-hari, pasien afasia harus menggali berbagai macam ide sendiri terutama dalam komunikasi verbal. Chapey menggarisbawahi pentingnya tugas-tugas yang memungkinkan lebih dari satu respon dalam penanganan afasia, terutama untuk melatih penemuan kata.

Materi terapi dipilih berdasarkan wawancara, observasi, dan tes penulis mendapatkan data bahwa pasien mengalami kesulitan dalam berkomunikasi verbal maupun non-verbal, dikarenakan pasien di diagnosa mengalami afasia global. 
Sesuai dengan modalitas yang dimiliki pasien juga yaitu visual (penglihatan) dan auditory (pendengaran), maka penulis memilih beberapa kategori untuk menjadi materi terapi diantaranya yaitu, pakaian dan peralatan makan. Kategori pakaian (kerudung, baju, jaket) Kategori peralatan makan (piring, sendok), Kategori peralatan mandi (gayung, handuk, sabun mandi, sikat gigi dan pasta gigi)

Berikut ini adalah langkah-langkah metode Intervensi semantic divergen, diantaranya sebagai berikut : a. Flash Card: diperlihatkan dihadapan pasien agar pasien dapat menunjuk flash card sesuai dengan instruksi.

b. Benda Asli: diperlihatkan dihadapan pasien agar pasien dapat menunjuk flash card sesuai dengan instruksi.

Metode terapi komunikasi total adalah terapi yang dikembangkan di Negeri Belanda ini dimaksudkan bagi pasien-pasien dengan afasia berat dan lingkungannya. Pasien disodori segala macam cara komunikasi yang dapat ia pahami dan gunakan (dengan cara belajar). Cara-cara ini ialah; menunjuk, menyatakan besarnya sesuatu, memberi gerak-isyarat, menggambar, menulis dan mencari dalam kamus kantong, di samping menggunakan bahasa biasa. Kamus kantong berupa kumpulan kata-kata dan gambar-gambar yang disusun dalam sejumlah kategori, seperti makan, minum, angkutan. Lingkungan (partner, keluarga, tenaga perawatan) pun belajar menggunakan kamus kantong ini.

Adapun tes awal yang dilakukan kepada klien sebagai berikut :

Tabel 4. Tes Awal

\begin{tabular}{|c|c|c|c|}
\hline \multirow[t]{2}{*}{ No. } & \multirow[t]{2}{*}{ Stimulus } & \multicolumn{2}{|c|}{ Respon } \\
\hline & & B & $\mathbf{S}$ \\
\hline \multicolumn{4}{|c|}{ Kategori pakalan } \\
\hline 1 & Kerudung/ Jilbab & & 0 \\
\hline 2 & Baju & & 0 \\
\hline 3 & Jaket & & 0 \\
\hline \multicolumn{4}{|c|}{ Kategori peralatan makanan } \\
\hline 4 & Piring & & 0 \\
\hline 5 & Sendok & & 0 \\
\hline \multicolumn{4}{|c|}{ Kategori peralatan mandi } \\
\hline 6 & Gayung & & 0 \\
\hline 7 & Handuk & & 0 \\
\hline 8 & Sabun mandi & & 0 \\
\hline 9 & Sikat gigi & & 0 \\
\hline 10 & Odol/Pasta gigi & & 0 \\
\hline & Jumlah & & 0 \\
\hline
\end{tabular}

Keterangan :

RB: Respon Benar, skor 1 jika pasien dapat menunjuk dengan benar yang sesuai dengan instruksi yang diberikan.

RS: Respon Salah, skor 0 jika pasien tidak dapat menunjuk dengan benar yang sesuai dengan instruksi yang diberikan. 
Evaluasi

Cara evaluasi program dengan cara membandingkan tes awal sebelum terapi dan tes akhir sesudah dilaksanakannya terapi.

Tabel 5. Perbandingan Tes Awal dan Tes Akhir

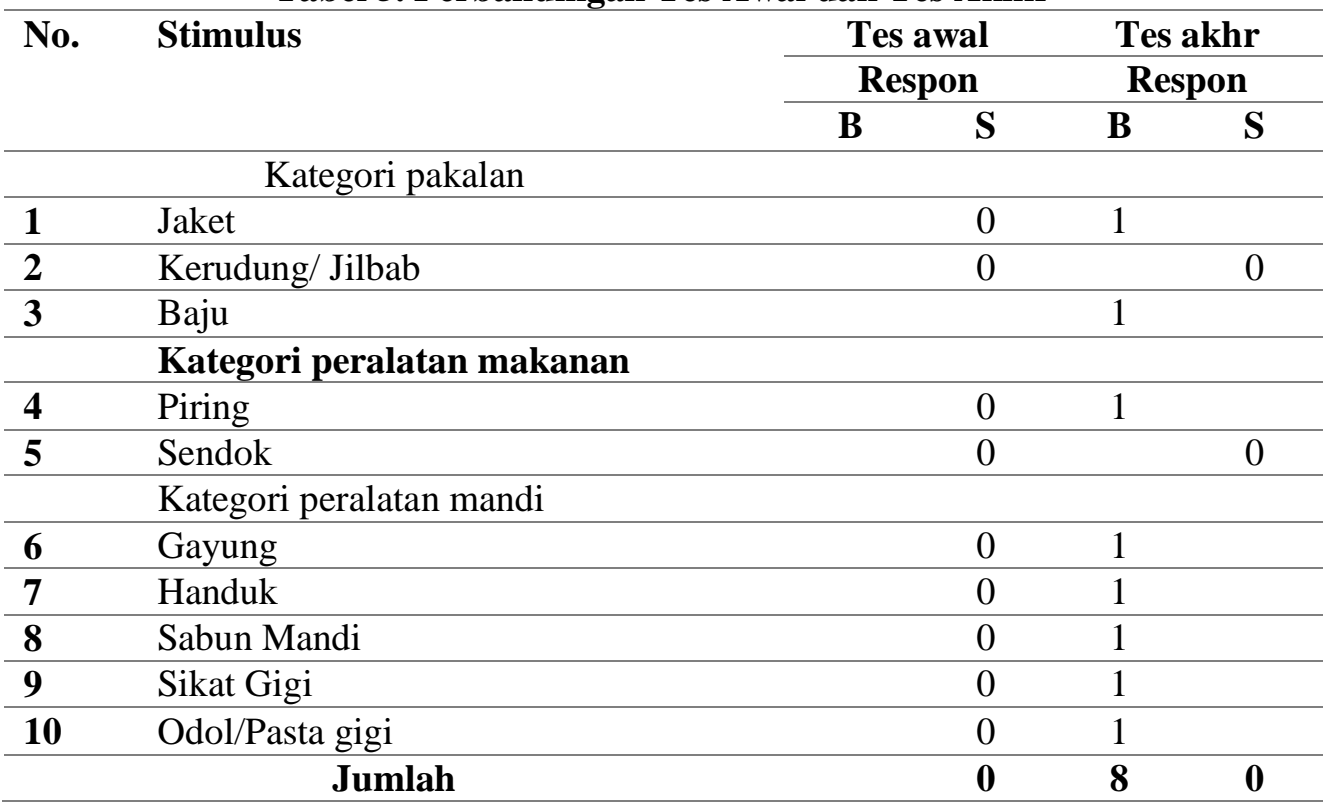

Setelah dilakukan terapi sebanyak 20 kali pertemuan dan 1 kali evaluasi, hasilnya pasien mengalami kemajuan dalam kemampuan menunjuk tingkat kata bendanya.

Dari hasil tes awal, pasien mendapatkan skor 0 poin. Sedangkan dari hasil tes akhir pasien mendapatkan skor 8 poin (dari hasil maksimal 10 poin). Maka pasien mengalami peningkatan skor 8 poin. Untuk menentukan kriteria keberhasilan,yaitu sebagai berikut:

Kriteria keberhasilan kemampuan menunjuk tingkat kata benda pasien adalah :

$$
\text { QUOTE X 100\% }=\text { QUOTE }=\mathbf{8 0 \%}
$$

Maka dari itu diketahui bahwa program meningkatkan kemampuan menunjuk tingkat kata benda yang telah dilakukan terhadap pasien, keberhasilannya adalah sebagai berikut: 
Tabel 6. Skala Keberhasilan Terapi

\begin{tabular}{llll}
\hline No & Respon Benar & Skala Persentase & Skala Keberhasilan \\
\hline 1 & $\mathbf{6 - 1 0}$ & $\mathbf{5 0 \%}-\mathbf{1 0 0 \%}$ & Berhasil \\
\hline 2 & $0-5$ & $0 \%-50 \%$ & Tidak Berhasil \\
\hline
\end{tabular}

Berdasarkan hasil diatas diketahui bahwa klien mengalami peningkatan dalam kemampuan menunjuk tingkat kata benda yaitu mengalami peningkatan sebanyak 8 poin dengan persentase $80 \%$, dengan demikian dapat disimpulkan bahwa terapi Berhasil.

\section{KESIMPULAN}

Berdasarkan hasil terapi kepada pasien yang berdurasi selama 50 menit, frekuensi 3 kali dalam satu minggu sebanyak 20 kali pertemuan untuk meningkatkan kemampuan menunjuk tingkat kata benda dengan menggunakan metode Komunikasi Total diperoleh peningkatan kemampuan sebanyak 8 poin.

Penulis dapat menyimpulkan bahwa metode Komunikasi Total ini dapat memudahkan pasien dalam proses menunjuk tingkat kata benda pada kasus Afasia Global ini mengalami peningkatan, maka berdasarkan kriteria keberhasilan terapi yang telah penulis buat, terapi yang pernah penulis lakukan kepada pasien termasuk kategori "Berhasil".

Hal ini didukung oleh angket pernyataan sesudah terapi, menyatakan pasien puas pada pelayanan dan hasil terapi yang dilakukan 20 kali pertemuan. Keberhasilan terapi juga dapat dipengaruhi oleh kesadaran pasien akan gangguan yang pasien alami dan motivasi dari diri pasien sendiri untuk bisa lebih baik lagi. Pasien rajin terapi ke rumah sakit dan latihan sendiri dirumah setiap harinya, dari lingkungan keluarga tanpa hentinya memberi pasien dukung.

\section{- DAFTAR PUSTAKA}

Afiyanti, Yati. 2014. Metodologi Penelitian Kualitatif Dalam Riset Keperawatan. Jakarta: PT. Raja Granfindo Persada.

Dharmaperwira-Prins, (1996). TADIR Tes Afasia untuk Dianosis informasi Rehabilitasi. Jakarta: Balai Penerbit Fakultas Kedokteran Universitas Indonesia.

Dharmaperwira-Prins (2002). Afasia Deskripsi Pemeriksaan dan Penanganan. Jakarta: Balai Penerbit Fakultas Kedokteran Universitas Indonesia.

Lestari, Endang. (2006). Komunikasi Yang Efektif. Jakarta: LAN Jakarta.

Lumbantobing. (2013). Neurologi Klinik Pemeriksaan Fisik dan Mental. Jakarta: Badan Penerbit Fakultas Kedokteran Universitas Indonesia.

Manurung, Melva. (2017). Dukungan Keluarga Dengan Motivasi Dalam Melakukan ROM Pada Pasien Pasca STROKE di RSU HKBP BALIGE Kabupaten Toba Samosir. Idea Nursing Jurnal. No 3, hal 4. 
Misbach, Jusuf. (2011). Stroke Aspek Diagnostik, Patofisiologi, Manajemen. Jakarta: Badan Penerbit Fakultas Kedokteran Universitas Indonesia.

Nazir. Moh. (2005). Metode Penelitian. Bogor Selatan: Ghalia Indonesia.

Panji Dewi. (2011). Stroke Bukan Akhir Segalanya. Jakarta: Elex Media Komputindo.

Peraturan Menteri Kesehatan No:81. (2014). Tentang Standar Pelayanan Terapi Wicara.

Purwani, Dwi. (2017). Stroke's Home Care. Yogyakarta: Healthy. Sardjono. (2014). Terapi Wicara. Jakarta: Departemen Pendidikan Nasional.

Setyono, Bambang. (1998). Terapi Wicara untuk Praktisi Pendidikan dan Kesehatan. Jakarta: EGC.

Subyantoro. (2013). Gangguan Berbahasa Mengenali Untuk Mengantisipasi Sejak Dini. Yogyakarta: Ombak.

Tammase, J. (2013). Stroke dan Pencegahannya. Makasar: Identitas Universitas Hasanudin. 